\title{
Mizan
}

JURNAL ILMU SYARI'AH

\section{VOL. 2 NO. 2 DESEMBER 2014}

Diterbitkan oleh Program Studi Akhwal al Syakhsyiyyah, Fakultas Agama Islam Universitas Ibn Khaldun Bogor. Mizan; Jurnal Ilmu Syariah mengkhususkan diri dalam pengkajian ilmu-ilmu Syariah, Hukum Keluarga dan Studi Islam. Terbit dua kali dalam satu tahun di setiap bulan Juni dan Desember.

\section{Advisory Editorial Board}

Ending Bahruddin (Universitas Ibn Khaldun Bogor)

Didin Hafidhuddin (Universitas Ibn Khaldun Bogor)

Ahmad Mukri Aji (UIN Syarif Hidayatullah Jakarta)

Maemunah Sa'diyah (Universitas Ibn Khaldun Bogor)

Salman Maggalatung (UIN Syarif Hidayatullah Jakarta)

Muhammad Munir (International Islamic University - IIU Islamabad Pakistan)

Muhammad Kholil Nawawi (Universitas Ibn Khaldun Bogor)

Hendri Tanjung (Universitas Ibn Khaldun Bogor)

Nur Rohim Y (UIN Syarif Hidayatullah Jakarta)

Ahmad Sobari (Universitas Ibn Khaldun Bogor)

Kamalludin (Universitas Ibn Khaldun Bogor)

Irfan Syauqi Beik (Institut Pertanian Bogor)

Editor in Chief

Syarifah Gustiawati Mukri

\section{Editors}

Suyud Arif

Sulaeman Madjid

Firman Mustahidin

\section{Asisten to The Editors}

Faturrahman Kamal

Rukmi Dwiastuti

\section{Alamat Redaksi}

Fakultas Agama Islam Universitas Ibn Khaldun Bogor Jawa Barat

Jl. KH. Sholeh Iskandar KM. 2 Kedung Badang Tanah Sareal Bogor 16162

Telp. (62-251) 8356884, Faks. (62-251) 8356884

Website: http://www.uika-bogor.ac.id/, E-mail: jurnalmizan.uikabogor@gmail.com

Permalink: https://uika-bogor.academia.edu/JurnalMizanUIKABogor 


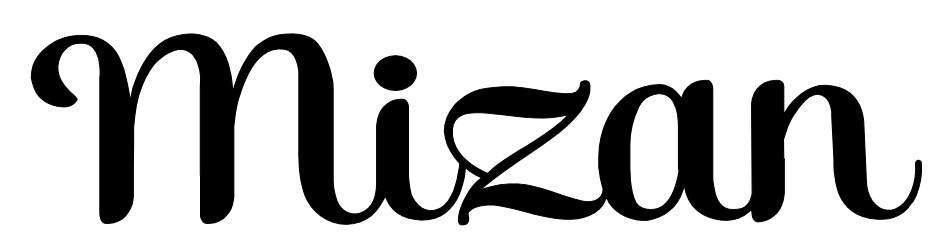

JURNAL ILMU SYARI'AH

Menyambut baik kontribusi dari para ilmuwan, sarjana, profesional, dan peneliti dalam disiplin ilmu Syariah, Hukum Keluarga, dan Studi Islam untuk dipublikasi dan disebarluaskan setelah melalui mekanisme seleksi naskah, telaah mitra bebestari, dan proses penyuntingan yang ketat. 


\section{DAFTAR ISI}

141-152 Metode Memahami Hadis

Ahmad Sobari

153-166 Ta'dib Dalam Kacamata Undang-Undang Nomor 23

Tahun 2004 Tentang Penghapusan Kekerasan Dalam Rumah Tangga (PKDRT)

Muhammad Ishar Helmi

167-182 Resepsi Pernikahan; Dasar Hukum dan Urgensinya Terhadap Perceraian

Ahmad Farhan Subhi

183-232 Konsep Jihad Dalam Perspektif Alquran; Studi Tematik

Dalam Tafsir al-Kasysyaf Atas Ayat-Ayat Jihad

Agus Handoko

233-244 Miss World Muslimah Dalam Perspektif Islam

Nabila Hassa

245-254 Perda Syariah Dalam Otonomi Daerah

Ummu Salamah \& Reinaldo Rianto

255-274 Etika dan Moralitas Politik Anggota Dewan

Nur Rohim Yunus 
ARTIKEL-ARTIKEL

MIZAN; JURNAL ILMU SYARIAH TELAH TERINDEKS DAN ONLINE PADA:

Google

$\bigoplus$ academia.edu

OAJ Open Academic

.net

ISSN: 2089-032X 